\title{
INOVAÇÃO E GESTÃO DE COMPETÊNCIAS POR ERIC CLAPTON
}

\author{
Por Luiz Carlos Di Serio
}

Professor do Departamento de Administração da Produção e de Operações da Escola de Administração de Empresas de São Paulo, Fundação Getulio Vargas - São Paulo - SP, Brasil

luiz.diserio@fgv.br

\section{Agnaldo Pedra}

Mestre em Administração de Empresas pela Escola de Administração de Empresas de São Paulo, Fundação Getulio Vargas - São Paulo - SP, Brasil

agnaldo.pedra@gmail.com

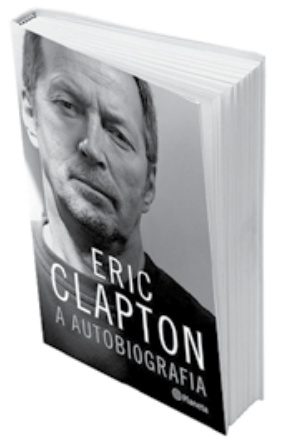

ERIC CLAPTON, A AUTOBIOGRAFIA

De Eric Clapton. São Paulo: Planeta do Brasil, 2007. 400 p.
A biografia de uma grande estrela da música pop internacional pode ser utilizada em ambientes acadêmicos e empresariais para discutir questões relacionadas à Administração de Empresas? Bem, se essa estrela atender pelo nome de Eric Clapton, existe uma abundância de temas a serem abordados.

Nas 400 páginas de Eric Clapton, a autobiografia, o autor relata sua trajetória de sucesso sem omitir detalhes dolorosos como o longo período no qual foi dependente de álcool e de drogas pesadas, além da perda de seu primeiro filho, com apenas 4 anos de idade. A paixão pelo blues e a busca obstinada pela perfeição foram os pilares que o tornaram uma lenda viva da música, que continua em intensa atividade, servindo de inspiração para novas gerações. É interessante notar como uma biografia pode, em alguns casos, analisada pela ótica de Administração de Empresas, apresentar diversos exemplos a serem utilizados tanto por professores em sala de aula como por executivos em suas reuniões de trabalho.

Nascido em 1945, na Inglaterra, Eric Clapton teve contato com a música desde a infância, mas, em 1957, ao assistir a Buddy Holly tocar no programa de TV "Sunday Night at the London Palladium", decidiu que rumo daria a sua vida e, ao ganhar o seu primeiro violão, iniciou um processo constante de desenvolvimento e aprimoramento de competências.

O conceito de desenvolvimento de competências já pode ser observado no início da sua carreira:
[...] comecei a aprender a tocar como Jimmy Reed, que em geral toca em 12 compassos, e cujo estilo foi copiado por incontáveis bandas de R\&B. Descobri que o ingrediente-chave era fazer uma espécie de boogie nas duas cordas graves da guitarra simplesmente pressionando a quinta corda no segundo traste e no quarto traste para fazer um tipo básico de movimento, enquanto tocava a corda mi do bordão ao mesmo tempo [...] Trabalhei nele até senti-lo como se fizesse parte do meu metabolismo (p. 43).

Em 1963, conseguiu o primeiro emprego como músico, na banda Yardbirds, que apresentava inovações para os padrões da época: "Enquanto a maioria das outras bandas estava tocando músicas de três minutos, nós pegávamos faixas de três minutos e es- 
ticávamos para cinco ou seis, e nisso a platéia ia à loucura, sacudindo a cabeça feito doida e dançando dos jeitos mais bizarros" (p. 60).

Na mesma época, Clapton também desenvolvia as suas próprias inovações técnicas: "Eu usava cordas finas na minha guitarra, com uma primeira corda muito delgada, o que facilitava para aumentar a tonalidade das notas, e não raro rebentava pelo menos uma corda ao tocar os trechos mais frenéticos" (p. 60).

Incomodado com o rumo trilhado pelos Yardbirds, Clapton aceitou o convite para juntar-se ao John Mayall and the Bluesbreakers, que, em 1965, já adotava uma estratégia de diferenciação:

Ele (John Mayall) ligou e perguntou se eu estaria interessado em me juntar ao seu grupo. Eu sabia que ele era do Marquee, e o admirava por estar fazendo exatamente o que sempre pensei que deveríamos ter feito com os Yardbirds. Ele tinha achado seu nicho e ali permanecia, percorrendo bons clubes e fazendo algo ímpar, sem querer botar para quebrar (p. 71).

Ganhando notoriedade, continuou desenvolvendo novas competências:

O que eu fazia era usar o captador do cavalete com o grave a toda, de modo que o som ficava muito denso e à beira da distorção [...] Eu tocava uma nota, segurava-a e fazia um vibrato com os dedos, até ela se sustentar, e aí a distorção tornava-se feedback. Foram todas essas coisas, mais a distorção, que criaram o que suponho que se poderia chamar de meu som (p. 90).

Embora estivesse feliz com os Bluesbreakers, Clapton também estava começando a ficar inquieto, nutrindo pensamentos sobre ser o líder de uma banda, e, em 1966, juntou-se a Jack Bruce e Ginger Baker para formar a banda Cream, que ganhou esse nome "[...] pelo simples motivo de que em nossa cabeça éramos a nata, a elite em nossos respectivos domínios" (p. 94).

$\mathrm{O}$ ambiente no Cream representou um forte estímulo:

A dinâmica de tocar em trio influenciou meu estilo enormemente, pois eu tinha que pensar em maneiras de produzir mais som [...] Minha técnica alterou-se bastante, pois comecei a tocar muito mais acordes com barra e a dedilhar cordas soltas para proporcionar uma espécie de bordão para meu trabalho solo (p. 96).

Em 1969, Clapton desenvolve uma nova competência, o canto, com base no conselho de Delaine Bramlett, que o aconselhou também a liderar a sua própria banda. Surgiu então a ideia de uma carreira solo, que começaria a germinar com o lançamento do seu primeiro álbum, no ano seguinte.

O início dos anos 1970 representou o que Clapton chamou de "anos perdidos", pelo seu vício em drogas: "Presumi que de algum modo estava imune e não seria fisgado. Mas com vício não tem conversa, e ele me envolveu como uma névoa [...] Foi muito insidioso, tomou conta da minha vida sem eu perceber" (p. 159).

Em 1982, finalmente reconhecendo sua condição de alcoólatra, inicia tratamento e, após se recuperar, sofre recaída em 1985 e volta para tratamento em 1987. Em 1991, o falecimento de seu filho Conor, aos 4 anos de idade, causa um profundo impacto na sua vida:

À primeira vista, o ano de 1991 foi horrendo, mas algumas sementes preciosas foram plantadas. Minha recuperação do alcoolismo adquiriu novo significado. Manter-me sóbrio realmente era agora a coisa mais importante e me deu um rumo quando pensei que não tivesse nenhum (p. 303).

Essa série de acontecimentos culminou naquilo que representa um exemplo de empreendedorismo e sustentabilidade de um negócio. Em viagens à sua casa em Galleon Beach, em Antígua, no Caribe, Clapton ficava cada vez mais desiludido com o número de viciados e bêbados que surgiam, ou talvez simplesmente "estivesse reparando mais neles" (p. 317).

Uma vez, ao voltar de uma dessas viagens, recebeu a sugestão de construir um centro de tratamento em Antígua:

O objetivo era construir a clínica em Antígua com vistas a atender toda a área do Caribe. Ficou entendido que, de início, poucos pacientes viriam das comunidades locais, e que precisaríamos promover o centro em outras regiões, atraindo pessoas dos Estados Unidos e da Europa que pagariam para ir até lá, e assim financiariam leitos para os nativos que não pudessem pagar (p. 318).

Sobre a necessidade de obter recursos financeiros para manter a clínica, Clapton relembra o convite que recebeu para tocar diante dos Clintons, em um concerto na Casa Branca, para comemorar os 30 anos das Olimpíadas Especiais: "O evento angariou uma enorme soma de dinheiro com o lançamento de um álbum do show e me ocorreu que era esse o caminho que devíamos seguir" (p. 326). Em 1999, Clapton organiza o show "Eric Clapton and Friends", com o objetivo de gerar recursos para o Centro Crossroads, e, em 2004, é realizado o primeiro "Crossroads Guitar Festival", que teria novas edições em 2007 e 2010.

Conceitos como inovação e desenvolvimento de competências destacam-se na academia e no ambiente empresarial. Convidamos os leitores, em especial os professores e os gestores de empresas, a incluir, em suas discussões sobre esses temas, alguns dos inúmeros exemplos que podem ser extraídos deste livro. Estamos convencidos de que eles proporcionarão um novo e importante estímulo aos seus alunos e colaboradores. 